\title{
COMPARISON OF VARIOUS COMMERCIAL PREPARATIONS OF MELATONIN IN IMMATURE RATS
}

\author{
P. V. TIGGHELAAR* AND A. V. NALBANDOV \\ Department of Physiology and Department of Animal Science, \\ University of Illinois, Urbana, Illinois 61801, U.S.A.
}

(Received 5th November 1970)

\begin{abstract}
Summary. Daily injections of various commercial preparations of melatonin into immature female rats yielded different results. Melatonin obtained from Regis and Sigma resulted in decreased ovarian and uterine weights when compared to controls, while melatonin obtained from Calbiochem and Nutritional Biochemicals did not alter ovarian or uterine weights. No change was noted in anterior pituitary weights in any of the groups. At present, the explanation for these differences is unknown.
\end{abstract}

The pineal gland has been shown to have an inhibitory influence on certain reproductive functions in mammals (Kitay, 1967). In female rats, pinealectomy results in premature vaginal opening and ovarian hypertrophy. Pineal extracts are prepared differently by different research workers, but, in general, pineal extracts reverse the effects of pinealectomy (Meyer, Wurtman, Altschule \& Lazo-Wasem, 1961; Moszkowska, 1963). Melatonin is found in the pineal glands of all mammals tested (Wurtman, Axelrod \& Chu, 1964) and has been claimed by some to be the pineal hormone since the enzyme necessary for its synthesis (hydroxy-indole-O-methyltransferase) is located only in the pineal gland (Axelrod, MacLean, Albers \& Weissbach, 1961). In female rats, microgram doses of melatonin result in delayed vaginal opening, decreased ovarian weight, and a decreased incidence of the appearance of cornified cells in the vaginal smears (Wurtman, Axelrod \& Chu, 1963; Chu, Wurtman \& Axelrod, 1964). In the male rat, microgram doses of melatonin result in a decrease in the weight of the seminal vesicles and prostates (Motta, Fraschini \& Martini, 1967). Injecting microgram amounts of melatonin, however, has not given consistent results in different laboratories. Ebels \& Prop (1965) noted that melatonin injection had no effect on the gonadal weights of immature male or female rats or on the vaginal cycle of adult female rats. It does not appear likely that these differences are due to the age of the animal, the lighting conditions or the dose used.

Since the melatonin used by each group was obtained from different sources,

* Present address: Department of Anatomy and Physiology, Indiana University, Bloomington, Indiana 47401, U.S.A. 
the present study was undertaken to compare the biological effects of melatonin obtained from four different commercial sources.

Twenty-one-day-old female Holtzman rats were maintained on a regimen of $16 \mathrm{hr}$ light $/ 8 \mathrm{hr}$ darkness/24-hr period and were fed commercial food and tap water freely.

Melatonin was obtained from four commercial sources: Calbiochem (Los Angeles, California); Nutritional Biochemicals Corporation (Cleveland, Ohio); Regis Chemical Company (Chicago, Illinois); and Sigma Chemical Company (St. Louis, Missouri). Crystalline melatonin was stored frozen until the solutions were to be prepared. Fresh solutions were prepared weekly and were stored refrigerated. Melatonin from each source was dissolved in ethyl alcohol. After the addition of saline, $0.2 \mathrm{ml}$ of each solution contained $100 \mu \mathrm{g}$ melatonin in $2 \%$ ethyl alcohol. Subcutaneous injections of $100 \mu \mathrm{g}$ were given daily in the morning for 23 days. (Controls were injected with saline in $2 \%$ ethyl alcohol.)

Animals were killed by decapitation in the afternoon and the anterior pituitaries, ovaries and uteri were weighed.

TABLE 1

EFFECT OF VARIOUS COMMERGIAL PREPARATIONS OF MELATONIN IN IMMATURE RATS

\begin{tabular}{|c|c|c|c|c|}
\hline Source & $\begin{array}{c}\text { No. of } \\
\text { rats }\end{array}$ & $\begin{array}{l}\text { Final body } \\
\text { wt }(g) \\
(\text { Mean } \\
\pm S . E .)\end{array}$ & $\begin{array}{c}\text { Ovary } \\
\text { wt }(m g) \\
(\text { Mean } \\
\pm S . E .)\end{array}$ & $\begin{array}{c}\text { Uterus } \\
w t(m g) \\
(M e a n \pm S . E .)\end{array}$ \\
\hline Control & 8 & $143 \pm 3$ & $53 \cdot 4 \pm 2 \cdot 2$ & $234 \cdot 2 \pm 24 \cdot 2$ \\
\hline $\begin{array}{l}\text { Melatonin }(100 \mu \mathrm{g}) \\
\text { Calbiochem } \\
\text { Nutritional Biochemicals } \\
\text { Regis } \\
\text { Sigma }\end{array}$ & $\begin{array}{l}8 \\
8 \\
8 \\
8\end{array}$ & $\begin{array}{l}145 \pm 3 \\
143 \pm 2 \\
142 \pm 3 \\
142 \pm 4\end{array}$ & $\begin{array}{l}47 \cdot 8 \pm 1 \cdot 8 \\
51 \cdot 5 \pm 1 \cdot 2 \\
38 \cdot 6 \pm 3 \cdot 0^{*} \\
42 \cdot 0 \pm 2 \cdot 4^{*}\end{array}$ & $\begin{array}{l}234 \cdot 0 \pm 25 \cdot 4 \\
193 \cdot 9 \pm 11 \cdot 3 \\
152 \cdot 7 \pm 14 \cdot 9^{*} \\
147 \cdot 7 \pm 12 \cdot 0^{*}\end{array}$ \\
\hline
\end{tabular}

No difference was noted in the weights of the anterior pituitaries of the five groups. The ovarian and uterine weights of animals injected with melatonin obtained from Calbiochem and Nutritional Biochemicals did not differ from the ovarian and uterine weights of the control group, but the ovarian and uterine weights of animals injected with melatonin from Sigma or Regis were shown to be significantly lower than those of the control group (Table 1).

Studies cited in the literature on the effects of exogenous melatonin on reproductive systems have not given consistent results. Since Wurtman obtained his melatonin from Regis, and Ebels \& Prop obtained their melatonin from Calbiochem, the difference in the biological effects of melatonin reported by these two laboratories could be explained by our results. Thieblot, Berthelay \& Blaise (1966) noted that melatonin injection increased the ovarian and uterine weights in the female rat and increased the seminal vesicle weights in the male rat. Since the source of their melatonin was not given, it is difficult to reconcile their results. 
Two possible explanations exist to explain the differences in biological activity of melatonin obtained from the four commercial sources cited: (a) the material obtained from Sigma and Regis is, in fact, melatonin and the results cited by Wurtman give a true picture of the effects of this compound which has been isolated from the pineal gland. If this is true, the melatonin obtained from Calbiochem and Nutritional Biochemicals may be defective in some way; (b) melatonin obtained from Sigma and Regis may be contaminated and the biological effects attributed to melatonin may be due to some contaminant present. Tests are in progress in our laboratory to determine this.

The function of the pineal gland has long been a mystery in mammalian physiology. As long as the biological effect of melatonin differs among various chemical companies, or among lots within the same company, work toward the solution of the function of this gland will be hampered.

\section{Work presented here was supported by USPH Grant MH-10715.}

\section{REFERENCES}

Axelrod, J., MacLean, P. D., Albers, R. W. \& Weissbach, H. W. (1961) Regional distribution of methyl transferase enzymes in the nervous system and glandular tissues. In: Regional Neurochemistry. Eds. S. S. Kety and J. Elkes. Pergamon Press, Oxford.

Chu, E. W., Wurtman, R. J. \& AxrLrod, J. (1964) An inhibitory effect of melatonin on the estrous phase of the estrous cycle of the rodent. Endocrinology, 75, 238.

EbeLs, I. \& Prop, N. (1965) A study of the effect of melatonin on the gonads, the oestrous cycle and the pineal organ of the rat. Acta endocr., Copenh. 49, 567.

KrTAY, J. I. (1967) Possible functions of the pineal gland. In: Neuroendocrinology. Eds. L. Martini and W. F. Ganong. Academic Press, New York.

Meyer, C. J., Wurtman, R. J., Altschule, M. D. \& Lazo-Wasem, E. A. (1961) The arrest of prolonged estrus in "middle-aged" rats by pineal gland extract. Endocrinology, 68, 795.

Moszkowska, A. (1963) L'antagonisme épiphyso-hypophysaire. Annls Endocr. 24, 215.

Motta, M., Fraschini, F. \& Martini, L. (1967) Endocrine effects of pineal gland and of melatonin. Proc. Soc. exp. Biol. Med. 126, 431.

Thieblot, L., Bertheray, J. \& Blaise, S. (1966) Effet de la melatonine chez le rat mâle et femelle. I. Action au niveau des gonades et des annexes. Annls Endocr. 27, 65.

Wurtman, R. J., Axelrod, J. \& Chu, E. W. (1963) Melatonin, a pineal substance: Its effect on the rat ovary. Science, N.Y. 142, 1071.

Wurtman, R. J., Axrlrod, J. \& ChU, E. W. (1964) The relation between melatonin, a pineal substance, and the effects of light on the rat gonad. Ann. N.Y. Acad. Sci. 117, 228. 